\title{
Why Percy can't think: A response to Bailin
}

\section{Donald L. Hatcher}

\section{Baker University}

\begin{abstract}
In "The Problem with Percy: Epistemology, Understanding and Critical Thinking," Sharon Bailin argues that critical thinking skills do not generalize because students do not understand the larger epistemological picture in which to situate the importance of arguments and reasons. More plausible explanations are: (1) instructors across the disciplines do not give assignments requiring critical thinking (CT) skills, (2) single courses in CT have little effect, (3) pragmatic arguments showing the effectiveness of CT are more effective than epistemological arguments with the average student. So to achieve the generalization of the logical skills and intellectual dispositions inherent in CT courses, CT thinking cannot be departmentalized.
\end{abstract}

Résumé: Sharon Bailin avance que les habilités de la pensée critique ne s'appliquent pas aux arguments de toutes les disciplines parce que les étudiants ne comprennent pas le plus large contexte épistémologique dans lequel ces arguments se situent. Je propose d'autres explications pour cette absence de transfert. (1) Les enseignant(e)s n'assignent pas des devoirs qui exigent la pensée critique. (2) Un simple cours de pensée critique et d'argumentation a très peu d'effet sur la pensée des étudiant(e)s. (3) 11 y a des arguments pragmatiques qui appuient l'idée que la pensée critique est plus efficace pour les étudiant(e)s moyens que des arguments épistémologiques. Alors, pour maximiser le transfert des habiletés et des dispositions de la pensée critique, celles-ci ne devraient pas s'enseigner dans seulement une discipline.

Keywords: critical thinking

In her thought-provoking paper, "The Problem with Percy: Epistemology, Understanding and Critical Thinking"' Sharon Bailin provides a description of a fictitious student named Percy-one with intellectual characteristics all too familiar to teachers who emphasize the importance of critical thinking in their courses. When asked to write a critical paper on some topic, one that both presents and supports his own ideas, Percy responds by saying "Oh! So you want us to base our conclusions on reasons and evidence"(Bailin, 161-162), as if giving reasons were not something done in the average college class. For Percy, this is something done only in critical thinking class, not across the curriculum.

The problem, according to Bailin, is not that Percy lacks the proper skills or dispositions, but that "Percy does not appreciate the role of reasons in inquiry and knowledge ... He does not understand the enterprise of knowledge creation and 
evaluation, an enterprise constituted by the offering and assessing of reasons ..... Without some appreciation of the nature of inquiry, without a larger epistemological picture in which to situate (the importance of arguments and reasons) the practice must seem to him like an arcane game with arbitrary rules" (ibid., 164).

While Bailin is not clear whether or not Percy has actually had a formal course in critical thinking, she assumes that her student has some understanding of the practice, arcane though it may seem, of trying to support his ideas with reasons. The problem is, according to Bailin, Percy is disposed to use these skills only in certain contexts. So the disposition to think critically is not generalized to academic settings beyond his critical thinking class, such as Bailin's Philosophy of Education class (Bailin, 164). As a result, it is natural for Percy to say "Oh! So in this class you want us to base our conclusions on reasons and evidence" (Bailin, 162). That is to say, the Percy's of the world have, at least in their minds, managed to departmentalize critical thinking. For them, supporting ideas with evidence and arguments or honestly evaluating the ideas of others is not something they are inclined to do in all contexts.

For teachers who believe that teaching students to think critically is one of, if not the, most important challenges in higher education, a challenge just as important to teaching students to read, write, and do math well, it is a great loss for students to think of critical thinking as a special, departmentalized practice. Just as teachers do not expect students to read and write well only in written composition classes, they should not be content for students to apply the standards of rigorous thought only in critical thinking class.

If we assume that Bailin's characterization of the problem is accurate and that this problem is common, the question is how should teachers minimize the number of students with Percy's attitude towards critical thinking? How do we make sure students see that critical thinking skills are essential beyond the obligatory critical thinking course?

Bailin's recommendation is that teachers go beyond the typical critical thinking course that focuses on teaching those skills and dispositions necessary for assessing reasons. She proposes that critical thinking courses attempt a rigorous justification of rational inquiry in general. She believes that if students are given such a deep understanding of the nature and importance of critical thinking, students will no longer think of critical thinking as merely one way among others to approach an issue. Students will understand that the skills and dispositions of critical thinking are co-extensive with all domains of serious inquiry, regardless of context or discipline. Students will see that serious thinking in any area requires skills that form the core of critical thinking: evaluating reasons and evidence, drawing proper inferences, and presenting sound argumentation.

To this end, Bailin offers two strategies: one negative and one positive. The first strategy is based on a conceptual analysis of the concept of critical thinking. The latter is more speculative. On the negative or what to avoid side, she says if 
teachers are to teach critical thinking, they must avoid teaching that what counts as knowledge requires certainty and that knowledge is based on authority. This is because, if certainty is a necessary condition for knowledge, skepticism follows. If knowledge is thought to be based on authority, then the importance of assessing reasons and evidence is minimized. But assessing reasons and evidence lies at the core of critical thinking. So, if critical thinking is to be taught effectively, knowledge claims must not be treated as either certain or as based on authority. Second, teachers must avoid all forms of radical relativism-philosophies that undermine the possibility of objective inquiry. If students believe the epistemic warrant for any belief is simply relative to a person's historical perspective, academic discipline, or conceptual frame, then serious thought and inquiry are undermined from the beginning. ${ }^{2}$ Students will not try to evaluate critically what they believe to be unquestioningly true or what is ultimately a matter of personal taste, cultural perspective, or departmental methodology. Serious inquiry and radical relativism are incompatible (Bailin, 167).

On the positive side, Bailin recommends explaining to students the "assumptions which underpin our practice of critical thinking" (Bailin, 167). These epistemological assumptions implicit to the practice of critical thinking include "a belief in reason, a belief in the possibility of rational justification in terms of criteria and standards,...a belief in the desirability of acting on the basis of rationally justified beliefs, and a belief that many of our particular beliefs or criteria could be mistaken or inappropriate" (Bailin, 167). She is prescribing what some might call a "critical thinking appreciation course" with a heavy dose of epistemology.

While such a proposal will no doubt appeal to many teachers of philosophy, the question is whether there is any evidence that such instruction in the epistemological foundations of critical thinking will go very far towards curing students who, like Percy, see critical thinking as something only done in critical thinking classes. For a number of reasons, I remain skeptical.

First (and this is admittedly anecdotal), given a good deal of experience with trying to teach critical thinking skills and dispositions to both students and faculty members not trained in philosophy, I am skeptical of the effects of any single course doing the job, no matter how well the material demonstrates the value of critical thinking. First, there is some empirical evidence that even two-semester sequences have little long term effect on critical thinking skills or dispositions. In giving the California Critical Thinking Skills Test to freshmen completing the sequence and then the post-test to seniors, the data indicates that students who possess fairly sophisticated critical thinking skills at the end of a year-long, freshmen critical thinking course often lose them by the time they are seniors. ${ }^{3}$ If a critical thinking course were sufficient to make critical thinking skills and dispositions "second nature" to students, surely a two-semester sequence would suffice. So, even if one is successful in explaining the value of critical thinking, there is no guarantee that students will remember or use what they have learned after com- 
pleting the course. The evidence is negative.

Rather than lacking a sophisticated epistemology, perhaps a more realistic account of the "problem of Percy" is what one might call "the politics of pedagogy." After ten years of teaching a required two-semester critical thinking sequence to college freshmen, I believe the problem with critical thinking skills not generalizing to other settings is not an inadequate conceptual understanding of critical thinking. In a typical critical thinking course, most students can be taught to understand very well the importance of assessing the reasonableness of alternative positions and supporting their ideas with good reasons. I would suggest that one important reason critical thinking skills do not generalize is that too many professors across the curriculum do not emphasize the importance of these critical thinking skills. When Bailin has Percy say, "So in THIS class, YOU want us to base our conclu" sions on reasons and evidence," it is reasonable to infer that in MOST other classes Percy has not been asked to do so. Otherwise, his surprised response to Bailin's assignment would not be appropriate. Hence, the problem is not that the skills and dispositions taught in a critical thinking class are not adequately understood and appreciated. A more reasonable explanation is, for a variety of reasons, too many professors remain reluctant to make assignments that would reinforce those skills and dispositions students have learned in their critical thinking classes. Given Percy's response to Bailin's assignment, too few professors ask students to research difficult issues and material, to evaluate the reasonableness of the alternative positions, and to articulate their conclusions in forceful argumentative prose.

Why is this? What are these reasons? ${ }^{4}$ Given my experience, some refuse to assign critical papers or give essay tests that would require students to exhibit such skills because they so despise grading student writing. In one instance, a colleague told me that he had given up assigning critical papers in his philosophy classes because he was so tired of grading student papers in the section of the required critical thinking class he taught. What message does it send to students when instructors in the disciplines so akin to critical thinking do not ask them to use their critical thinking skills in courses where such use would be so natural? The "Problem with Percy" is a natural outcome.

Second, there is also the problem of course load and class size. If teachers have too many students in their classes or too many classes, their reluctance to assign complicated writing assignments is understandable. Grading critical thinking exercises or papers is time consuming, so, if there are too many students, it is impossible for teachers adequately to complete the grading. Objective tests take the place of the essay that might ask a student to "Critically evaluate Socrates' argument that people do evil unwillingly," or the paper defending the reasonableness of a public policy over the alternatives.

Third, professors who do require papers or essays may not require students to support a position and defend it against possible objections. Some, for a variety of reasons, see giving reasons for one's ideas as something proper only in philosophy 
or critical thinking classes, but not in their disciplines. For example, some literature or art professors assign papers that involve creative interpretation rather than argumentative essays. Reflection and immediate insight take precedent over evidence and argumentation. Social science professors often assign the traditional resarch paper that is more a survey of the available literature on a topic rather than a position paper. Again, the result is that critical thinking skills are seen as something useful only in critical thinking classes, but not across the curriculum.

I have had Women's Studies teachers tell me that logic and reasoning were merely games people trained in philosophy play, usually to make others who may not be very good at them feel uncomfortable. Such teachers may present logic and reasoning to students as a male tool of oppression.

The point should be clear: faculty members in higher education do not agree, any more than Percy, on the value of critical thinking. So, until all voices are singing the same song, the Percy's of the world will surely continue to see critical thinking as just one approach among other equally valid ways of presenting ideas. (And, to be realistic, the prospect of all professors singing the same song about the nature and value of rationality is about as likely as a room full of philosophers agreeing on the validity of transcendental argumentation.)

In addition to faculty not agreeing on the value of logic and argumentation, I do not think explaining "the assumptions which underpin the practice of critical thinking" will have as much effect on student attitudes towards rationality as more pragmatic arguments that show the usefulness of critical thinking in a variety of areas-areas beyond the classroom. ${ }^{5}$ There are lots of important practical reasons for learning to be a good thinker, one who can honestly evaluate alternative positions or theses and decide which makes the most sense. For example, teachers could easily point out that the analytic skills taught in critical thinking classes are useful in nearly all professions. Who would want a physician, lawyer, accountant, or builder who could not evaluate the data, examine the options, and tell us which alternative made the most sense?

Finally, there is a problem of epistemological circularity when trying to convince the skeptic of the value of critical thinking. For example, given a good deal of experience with faculty members who teach critical thinking, I question whether having a sound theoretical understanding of critical thinking will have the desired effect on such skeptics as Percy. Twelve years ago, while working with a group of non-philosophy faculty on a critical thinking course to be required of all freshmen, I decided to start out having us work our way through Harvey Siegel's fine book Educating Reason. ${ }^{6}$ In spite of Bailin's criticism of Siegel, Siegel's book does a terrific job of arguing against McPeck and showing the centrality of critical thinking to all inquiry, regardless of the discipline. ${ }^{7}$ Siegel does as good a job as any of providing a deep understanding of the importance of giving good reasons in all inquiry. What I found in going through the book was that faculty who already endorsed the power and promise of rational argument responded well to the argu- 
ments in the book, but those who were not already convinced of the value of reason in education remained skeptical. In fact, it seems obvious that people who are not attuned to evidence and arguments will not be inclined to change their minds because of new "evidence and arguments."

Students who are not attuned to argumentation tend to be even worse. They, like Glaucon in Plato's Republic, see argument as a trick to get them to assent to what they strongly feel, deep in their hearts, is wrong. They see the critical thinking teacher as stacking the deck, not as an honest inquirer who is bringing up the relevant objections to or weaknesses with critical thinking. Critical thinking is a tool used by those clever at argument to oppress those who lack such intellectual abilities.

So the irony it seems, is that only those who are already "appropriately moved by reasons" will be convinced by the "arguments" for the value of critical thinking. Those who begin with no appreciation for or a distrust of arguments will not be swayed by argument. Plato may well have been correct when he proposed that the young be surrounded only with beautiful harmonious objects and sounds, an environment akin to reason. Then, being already friendly towards the rational, the children would naturally be responsive to argument. But we do not live in Plato's Republic.

Some might argue, however, that my anecdotal evidence implies that, for the most part, only philosophers teach critical thinking, to the exclusion of everyone else in academe. ${ }^{9}$ Surely, history teachers teach their students how critically to evaluate historical evidence. Surely, science teachers teach their students how to evaluate the strength of claims made in "the name of science." In claiming that critical thinking is not being taught across the curriculum, what then are these teachers teaching? If asked, surely these teachers would certainly claim they are teaching critical thinking.

There are a number of ways to respond to such a criticism. First, one might point out that disputes over who is "really" teaching critical thinking and who is not may be a function of there not being a broadly accepted definition of what critical thinking is and what it is not. So long as there is no universally accepted definition of critical thinking, one could argue that any discipline, not just philosophy, teaches critical thinking or at least some aspect of it. ${ }^{10}$ So, yes scientists and historians teach critical thinking. They just have a different conception than philsophers. For example, I recently saw an article in a university's alumna magazine titled, "Family Portraits: English Professor teaches critical thinking by tapping wealth of shared wisdom found in students' family lives." "For this "critical thinking" class, there was no study of logic, no instruction in argument analysis evaluation, and no opportunities for students to construct arguments. In the mind of the English professor, critical thinking meant students examining and reflecting upon their family tree and speculating on its effects on their lives. I suspect that such novel conceptions of critical thinking are not rare. 
Politically appealing as this, "let a thousand flowers bloom" approach to teaching critical thinking seems, it is problematic for a number of reasons, and should not be endorsed. First, without some agreed upon definition of critical thinking, how will teachers be able to assess whether or not they have indeed taught students to be critical thinkers? How will assessors devise standard tests of evaluation if there are no standard conceptions? How will curriculum committees know what courses fulfill a school's critical thinking requirement? These are important issues-issues the critical thinking movement has not adequately addressed. Even though this approach to critical thinking justifies everyone's claim that he or she teaches critical thinking, the problems are too great.

A second response is to bite the bullet and agree with the critic and admit that my position implies that only philosophers are teaching critical thinking. If critical thinking is construed as something akin to "the honest evaluation of alternatives with respect to available evidence and arguments," 12 then any course that purports to teach critical thinking must give some instruction on how to evaluate evidence and arguments. This implies that if a course is teaching critical thinking, then students must be given instruction in evaluating the logic (either formal or informal) of arguments, i.e., when indeed do reasons (premises) provide adequate support for a position (conclusion). Second, students must be shown how to apply these standards of reasoning to issues in any specific discipline where reasoned judgment is required. If these are necessary conditions (albeit perhaps not sufficient) of critical thinking, then teachers of many courses (even some philosophy courses) cannot claim to be teaching critical thinking.

No doubt, such a response will be less than popular because, in my experience, whenever I ask an auditorium full of teachers "Who is not teaching critical thinking?" no one ever raises his or her hand.

One way to split the horns of the dilemma between "anything goes" and "only courses with instruction in argument evaluation count as critical thinking courses" is to point out that almost any definition of critical thinking will imply that it is comprised of many skills and dispositions. Once we have a list of such skills and dispositions, then we can look at courses to see if any are in fact covered. So even though the course may not go the "whole nine yards" and include instruction in argument analysis, evaluation, and construction, by overtly teaching some of the skills and dispositions needed to engage in critical thinking, teachers all across the curriculum can say they are helping students develop their critical thinking skills.

This may seem to be the correct way to respond to the charge of the "philosophers' hegemony with respect to critical thinking," i.e., that my account of why "Percy can't think" seems to imply that only philosophers teach critical thinking. While critical thinking is taught in courses specifically designed to teach students to evaluate the reasonableness of alternative positions, those teachers who teach some of the skills and dispositions can claim to be doing their part, even if they do not cover the logic necessary for students to evaluate evidence and arguments. 
However, even this response is troubling. Indeed, if teaching such skills is truly widespread, it is hard to explain why students like Bailin's "Percy" are surprised when asked to write papers where they support their ideas with reasons. After all, why would teachers teach students how to evaluate sources or to be open-minded unless they intended for students to use these skills and dispositions to enhance their papers in those classes? So, if the "Percys of academe" are indeed surprised when asked to support their ideas with reasons, the implication is that not only is what is taught in critical thinking courses per se not being generalized, but the skills and dispositions essential for critical thinking are not being taught in other courses. This is because learning such skills makes sense only in the context of students evaluating and presenting reasons for their ideas or positions. For example, why would a teacher want students to be able to evaluate research sources? The ability to evaluate one's sources is valuable presumably because students will use these sources as reasons to support their ideas in papers or essays. Or, why would teachers emphasize such dispositions as being open-minded, if not because open-mindedness helps students honestly evaluate alternative positions or solutions, where close-mindedness means that viable alternatives are either ignored or not given a fair evaluation-and the importance of not ignoring alternatives or treating each fairly is in the context of writing a position paper or essay. So, again, if these skills were widely taught, there should be no surprise when papers are assigned with the emphasis on supporting the theses with good reasons. Hence, if Bailin's "Percy problem" is real, then it follows that the importance of giving good reasons for one's position is not being taught across the curriculum, and indeed the teaching of critical thinking does not extend beyond those who consciously focus on teaching students to evaluate arguments, and give good reasons for their positions.

So, in conclusion, if we assume that campuses are filled with Percys and critical thinking is not something widely taught, rather than adopt Bailin's position of including more rigorous training in epistemology in critical thinking classes, I propose two steps. First, we get students interested in developing their critical abilities by appealing to their self-interest. We should spend time showing them how critical thinking skills, techniques, and strategies can be used to write more effective papers, to make wise decisions, and to convince others of the reasonableness of our ideas in a wide variety of areas. We should show them how social evils that most students oppose are often the product of uncritical thinking, e.g., prejudices are the result of hasty generalizations or not examining alternative explanations for peoples' behaviors. We should show them how many personal problems that young people have stem from holding unreasonable beliefs about what is important and what is not; e.g., we might go over some the theory behind Rational Emotive Behavior Therapy used by psychologist Albert Ellis and others. We might show them how critical thinking skills are just those skills which are coextensive with some of the more interesting and lucrative professions, e.g., 
practicing scientists, engineers, physicians, and lawyers each are skilled in the honest evaluation of alternatives with respect to available evidence and arguments. When critical thinking is shown to be co-extensive with their personal well-being and their future livelihood, students may take it more seriously and be more inclined to apply its skills whenever appropriate. Especially for young people, it is my experience that the practical takes precedence over the theoretical.

Second, just as English faculty members typically encourage colleagues to uphold the standards of good writing across the curriculum, those who teach critical thinking should do everything they can to convince other colleagues across the curriculum to emphasize the importance of students making reasoned judgments, supporting their ideas with strong evidence and arguments, and honestly evaluating alternatives. If class size or load is a problem, teachers must convince administrators that they cannot effectively meet the educational goal of enhancing students' critical thinking abilities without asking students to do a good deal of argument analysis and writing. This requires smaller classes. Only when critical thinking skills and dispositions are seen as an integral part of students' education will students engage in enough practice over their undergraduate education to internalize the important character traits and skills as second nature.

So while Sharon Bailin's agenda of enhanced epistemological understanding may work with the converted, I fear that the Percy's of world will go out the same door wherein they came. Only if people already value reason, will they take seriously the theoretical arguments showing how critical thinking is a pre-condition of and underlies all inquiry. Practically speaking, just as students will only take writing well seriously when all teachers both understand the nature of good writing and demand that students measure up to these standards, so critical thinking will only be taken seriously when all teachers understand its nature and value, and so demand that students exercise their critical thinking abilities in every class. For the Percy's of the world, as long as reasoning is seen as a trick with words, a tool of oppression, or one among other ways of persuasion, neither it nor the arguments for its importance will be taken seriously.

\section{Notes}

'A prior version of Bailin's paper was presented at the Pacific Division meeting of the American Philosphical Association in San Francisco, March 1994. I presented a version of this paper as a response. The published version of Bailin's paper is in Informal Logic, Vol. 19, Nos 2\&3 (1999) pp. $161-170$.

${ }^{2}$ For a more complete discussion of the problem of trying to unite critical inquiry with a relativist epistemology, see my "Should Anti-realists Teach Critical Thinking?" in Inquiry: Critical Thinking Across the Disciplines, Vol, 14, No, 4, 1995, pp. 29-35.

${ }^{3}$ My skepticism is partially grounded in the empirical research conducted over the last four years at Baker University. We have a required two-semester sequence for all freshmen that integrates instruction in critical thinking and written composition. We teach the freshmen how to both construct and evaluate arguments, and then to apply this knowledge to whatever they read and 
write. (For a complete description of the program see "Why Critical Thinking Should Be Combined with Written Composition, Informal Logic, Vol. 19, Nos. 2 and 3(1999)pp. 171-183.) To assess the program, we are now using the California Critical Thinking Skills Test (CCTST). We give the test to all freshmen the first day of class and the at the end of the second semester as part of their final exam. Over the past four years, the gain for the freshman year has averaged 2.8 points, which is a bit better than the 2.0 points gained by students used to validate the test. We give the test again to all seniors as part of a mid-term exam when the students take their senior capstone course, "Science, Technology, and Human Values." As the charts below show, the average freshman to senior gain is 3.4 points, a meager gain of .6 points over the scores at the end of their freshman year. It would seem that students committed to critical thinking as freshmen would be able to do somewhat better after two more years of college.

\section{Freshmen pre- and post-test scores using the California Critical Thinking Skills Test-Fall 1996 to Spring 2000}

$\begin{array}{llllllll}\text { Baker Freshmen } & \begin{array}{l}\text { Pre } \\ \text { Test }\end{array} & \begin{array}{l}\text { St. } \\ \text { Dev. }\end{array} & \begin{array}{l}\text { Post } \\ \text { Test }\end{array} & \begin{array}{l}\text { StD. } \\ \text { Dev. }\end{array} & \text { Diff } & \text { T } & \text { Sig } \\ \text { F96/S97 }(\mathrm{n}=152) & 14.9 & +/-4.0 & 18.3 & +/-4.1+3.4 & & \\ \text { F97/S98 }(\mathrm{n}=228) & 14.3 & +/-3.9 & 17.2 & +/-4.3+2.9 & & \\ \text { F98/S99 }(\mathrm{n}=177) & 15.5 & +/-4.7 & 17.9 & +/-4.7+2.5 & & \\ \text { F99/S00 }(\mathrm{n}=153) & 15.8 & +/-4.3 & 18.3 & +/-4.3+2.5 & & \\ \text { Mean }(\mathrm{n}=\mathbf{7 1 0}) & \mathbf{1 5 . 1} & +/-4.4 & \mathbf{1 7 . 9} & +/-4.5+2.8 & \mathbf{8 . 0} & <.001 \\ & & & & & & \\ \text { Comparison Group } & 15.4 & +/-4.6 & 17.4 & +/-4.7+2.0 & 2.4 & <.0075 \\ \text { Test Validation } & & & & & & \\ \text { Study (n=261) } & & & & & & & \end{array}$

\section{Freshmen to senior comparison of CCTST Scores-Fall 1996 to Spring 2000}

$\begin{array}{llll}\text { Baker Graduates } & \text { Freshmen } & \text { Seniors } & \text { Diff. } \\ \text { Grads. 2000 }(\mathrm{n}=102) & 15.2 & 19.4 & +4.2 \\ \text { Grads. 2001 }(\mathrm{n}=55) & 152 & 17.8 & +2.6 \\ \text { Mean }(\mathrm{n}=\mathbf{1 5 7}) & \mathbf{1 5 . 2} & \mathbf{1 8 . 6} & \mathbf{+ 3 . 4}\end{array}$

\footnotetext{
${ }^{4}$ Much of what follows is based on 20 years of experience teaching critical thinking, setting up a required critical thinking program, evaluating critical thinking programs, training individual faculty members to teach critical thinking, and giving critical thinking workshops to teachers from across the curriculum. What may appear anecdotal in fact comes from a wealth of experience.

'See, for example Chapter One of Anne Spencer's and my text Reasoning and Writing: From Critical Thinking to Composition (Boston: American Press, 2000) There we link the value of critical thinking to job performance, solving social problems, rational choice, making ethical decisions, individual mental health, and, of course, academic performance in all disciplines.

${ }^{6}$ Harvey Siegel, Educating Reason (New York: Routledge, 1988). See Chapter One, pp. 18-31.

${ }^{7}$ See John McPeck, Critical Thinking and Education, New York: St. Martins, 1981.

- This is Harvey Siegel's definition of critical thinking from Chapter Two of Educating Reason.

${ }^{9}$ I am grateful to Informal Logic's reviewers for this criticism.
} 
${ }^{10}$ See my "Arguments for Another Definition of Critical Thinking," forthcoming Inquiry: Critical Thinking Across the Curriculum. There I argue that the lack of an agreed upon definition makes course design, assigning course credit, and assessment nearly impossible. Without a clear definition, anyone can claim to be teaching critical thinking because no one agrees on what it is. "Kansas Alumni, No. 2, 2000, p.19.

${ }^{12}$ Hatcher and Spencer, Reasoning and Writing: From Critical Thinking to Composition (Boston: American Press, 2000), p.1.

Donald L. Hatcher Department of Philosophy and Religion Center for Critical Thinking Baker University Baldwin City, KS 66006 